\title{
KAJIAN POTENSI OBJEK WISATA BUDAYA DI KAWASAN WISATA LOVINA
}

\author{
Kadek Arianti, Cok Istri Raka Marsiti, Ni Made Suriani, \\ Jurusan Pendidikan Kesejahteraan Keluarga \\ Universitas Pendidikan Ganesha \\ Singaraja, Indonesia
}

e-mail: ariantilellut@yahoo.com, raka.marsiti@undiksha.ac.id, made.suriani@undiksha.ac.id

\begin{abstract}
Abstrak
Penelitian ini bertujuan untuk mengetahui potensi objek wisata budaya di Kawasan Wisata Lovina. Penelitian ini merupakan penelitian deskriptif dengan lokasi penelitian yaitu di tujuh desa yang merupakan bagian dari Kawasan Wisata Lovina, diantaranya Desa Temukus, Tigawasa, Kaliasem, Kalibukbuk, Anturan, Tukad Mungga, dan Desa Pemaron. Teknik pengambilan sampel yang digunakan adalah teknik snowball. Pengumpulan data dilakukan melalui metode observasi dan wawancara yang menghasilkan jenis data primer dan telaah dokumen yang menghasilkan jenis data sekunder. Data dianalisis melalui 4 tahap yaitu (1) pengambilan data, (2) reduksi data, (3) penyajian data, (4) penarikan kesimpulan. Hasil dari penelitian ini adalah terdapat potensi wisata budaya di Kawasan Wisata Lovina yang meliputi (1) Bangunan bersejarah dan museum yang berupa Tugu Belanda dan Makam Keramat Karang Rupit dari Desa Temukus, Seka Roras, Sarkopah dari Desa Tigawasa, Puri Ayodya di Desa Kalibukbuk dan Pemandian Tirta Mumbul di Desa Anturan (2) Pusat seni dan kerajinan tangan yang berupa Krisna wisata oleh - oleh di Desa Temukus, Anyaman bambu (sokasi) di Desa Tigawasa, Art Shop Pantai Binaria dan Ingka (anyaman lidi) di Desa Anturan (3) Peninggalan keagamaan yang berupa Mertiwi di Desa Tigawasa, Candi Budha Kalibukbuk dan Pura Kawitan Majapahit di Desa Kalibukbuk, Pura Siwa Manik Dalang di Desa Pemaron, (4) Upacara Madyaning Karya Pamulungan Agung di Pura Labuan Aji dan Meboros Kijang (rusa) di Desa Tigawasa, Sampi Gerumbungan di Desa Kaliasem, Megebeg-gebegan dan Ngelawang Barong Bangkal di Desa Tukad Mungga, (5) Wisata Kuliner yang berupa Ikan bakar dan Kecap Meliwis di Desa Temukus, Gula Merah dan Timbungan di Desa Tigawasa.
\end{abstract}

Kata Kunci: Potensi, Wisata, Budaya, Kawasan Wisata Lovina

\begin{abstract}
The aim of this research was to describe about the cultural tourism potential in the Lovina Tourist Area. The current research was a description research with the located in 7 villages which is the part of Lovina Tourist Area, there are: Temukus, Tigawasa, Kaliasem, Kalibukbuk, Anturan, Tukad Mungga, and Pemaron Village. The data in this study were taken by snowball technique with the first informant is Mr. Nyoman Sutrisna.MM as head of the Tourism Government. The data collected by observation and interview method that result a primary data and document review that result a secondary data. Data were analyzed with the 4 steps, there are (1) data retrieval, (2) data reduction, (3) presented of data, (4) conclusion. The results of this study is states that there are a cultural tourism potential in Lovina Tourist Area which is : (1) Historical Building and Museum there are Monumen Tugu Belanda and Makam Keramat Karang Rupit in Temukus Village, Sekaa Roras and sarkopah from Tigawasa village, Puri Ayodya from Kalibukbuk, etc. (2). Art Centre and Handicraft which is Krisna wisata oleh oleh in Temukus village, Sokasi (bamboo handicraft) from Tigawasa village, and Art Shop in Kalibukbuk village. (3) Religious heritage such as Mertiwi in Tigawasa Village, Candi Budha Kalibukbuk and Pura Kawitan Majapahit in Kalibukbuk Village, Pura Siwa Manik Dalang in Pemaron Village, (4) Madyaning Karya Pamulungan Agung ceremony in Labuan Aji Tample and Meboros Kijang (Deer) in Tigawasa Village, Sampi Gerumbungan in Kaliasen Village, Megebeggebegan and Ngelawang Barong Bangkal in Tukad Mungga Village, (5) Culinary Tour like, grilled fish and Kecap Meliwis in Temukus Villave, Palm Sugar and Timbungan in Tigawasa Village.
\end{abstract}

Keywords: Potency, Travel, Culture, Lovina Tourist Area 


\section{PENDAHULUAN}

Pariwisata saat ini merupakan industri yang berkembang besar dalam pembangunan, baik skala regional dan nasional. Pariwisata cukup menjanjikan sebagai primadona karena banyak segi positifnya, pembangunan sektor pariwisata mampu mendorong pembangunan sektorsektor lain baik secara langsung maupun tidak langsung. Misalnya pengembangan kawasan pantai akan mendorong pembangunan bidang transportasi baik berupa perbaikan jalan maupun rute angkutan kendaraan umum. Disamping itu, pengembangan sektor pariwisata membuka peluang bagi penduduk sekitarnya untuk meningkatkan pendapatan masyarakat, menciptakan peluang kerja serta memperkenalkan kekayaan alam dan budaya bangsa. Pariwisata adalah salah satu jenis industri yang mampu menghasilkan pertumbuhan ekonomi yang cepat dalam penyediaan lapangan kerja, peningkatan penghasilan, standar hidup serta menstimulasi sektor-sektor produktivitas lainnya. Selanjutnya sebagai sektor yang kompleks, pariwisata juga meliputi industri kerajinan tangan dan cinderamata. Penginaan dan transportasi secara ekonomis juga dipandang sebagai industri (Pendit, 1999: 35), menyadari manfaat yang dieroleh dari pembagunan sektor pariwisata, maka pemerintah Indonesia sangat menaruh harapan pada sektor pariwisata untuk dimasa mendatang. Keberadaan industri pariwisata selain untuk melestarikan kebudayaan juga merupakan asset utama dalam pemasukan devisa Negara, pendapatan daerah, dan pendapatan masyarakat dengan munculnya peluang kerja bagi penduduk dimana objek tersebut dikembangkan (Erawan, 1994: 34) untuk itu pembangunan sektor pariwisata terus ditingkatkan dengan mengembangkan dan mendayagunakan sumber dan potensi kepariwisataan nasional yang ada agar dapat menjadi sumber kegiatan ekonomi yang makin dapat diandalkan.
Pengembangan pariwisata meliputi berbagai bidang, diantaranya adalah pengembangan wisata alam (pantai,

gunung, goa) dan pengembangan wisata budaya (upacara tradisional, pakaian tradisional, bangunan kuno, tari-tarian, makanan khas daerah). Kedua bidang tersebut sama-sama memiliki daya tarik khusus bagi wisatawan. Namun, jika dicermati cenderung wisatawan khususnya wisatawan mancanegara yang menjadi bidang daya tarik utamanya adalah bidang kebudayaan. Pariwisata alam nampaknya hanya menjadi "tempat beristirahat" bagi wisatawan. Sesuai dengan semangat otonomi daerah yang menyerahkan tugas pengembangan kebudayaan dan pariwisata kepada Dinas Pariwisata di masing-masing daerah, maka Dinas Pariwisata harus benar-benar menangkap pelimpahan tugas dan wewenang itu sebagai peluang untuk memajukan masyarakat di daerahnya. Sebagai contoh, dengan kekayaan budaya yang kita miliki, maka di setiap kabupaten atau kota Dinas Pariwisata minimal dapat mendirikan satu pusat atau sentra pariwisata budaya yang menampilkan keanekaragaman budaya di wilayahnya masing-masing. Bila kita kaji lebih dalam, ternyata yang menjadi tujuan para turis asing tersebut adalah ingin melihat kebudayaan Bali yang terkenal eksotik dan unik, yang berbeda dengan kebudayaan masyarakat mereka. Bila Bali tidak menawarkan kebudayaan masyarakatnya tersebut, maka tidak akan ada daya tarik para wisatawan untuk mengunjunginya. (http://bali-travelnews.com di akses pada tanggal 19 Oktober 2017). Hal itulah sebenarnya merupakan gambaran konkret dari konsep pariwisata budaya yang istilahnya sering disebut-sebut oleh para pengambil kebijakan (pemerintah) dan para akademisi, namun seringkali sulit untuk dijelaskan dalam definisi konseptual yang operasional, terutama dalam menyepakati konsep kebudayaan itu sendiri.

Budaya adalah salah satu bentuk fenomena geografi yang dimunculkan dari interaksi manusia sebagai penghuni bumi 
dan bumi sebagai tempat hunian manusia. Manusia merupakan faktor penentu dalam berinteraksi dengan lingkungan, interaksi manusia disini dimumculkan dengan eksploitasi sumber daya alam maupun sumber daya manusia. Budaya disini merupakan suatu cara untuk hidup berkembang dan dimiliki bersama oleh sebuah kelompok orang maupun seserorang yang kemudian akan diwariskan dari generasi ke generasi. Budaya terbentuk dari banyak unsur yang rumit termasuk sistem agama dan politik, adat istiadat, bahasa, perkakas, pakaian, bangunan dan karya seni. Dalam perkembangan yang semakin maju manusia terus menggali kreatifitas diri untuk meningkatkan kualitas dan kuantitas diri agar manusia tidak kalah bersaing dan mampu untuk terus bereksplorasi lebih jauh untuk memenuhi kebutuhannya. Sehingga dalam kreatifitas manusia disini munculah suatu kebudayaan yang merupakan hasil dari budaya. Ditinjau dari segi wujud kebudayaan, terdapat 3 aspek utama yaitu, ide (gagasan), wujud (bentuk), dan perilaku, dimana hasil ini ditimbulkan dari cita, rasa dan karsa yang senantiasa berkembang (Yoeti, 2006: 66), sehingga suatu daerah memiliki beragam jenis kebudayaan, karakteristik dan variasi kebudayaan daerah. Antara daerah satu dengan daerah yang lain akan terbentuk suatu kebudayaan dalam rangka menunjang kehidupan manusia terkait dengan lingkungan. Secara antropologi Indonesia, kebudayaan dalam perspektif klasik pernah didefinisikan oleh Koentjaraningrat sebagai keseluruhan sistem gagasan, tindakan, dan hasil karya manusia dalam rangka kehidupan masyarakat yang dijadikan milik diri manusia yang diperoleh dengan cara belajar.

Dalam pengertian tersebut, kebudayaan mencakup segala hal yang merupakan keseluruhan hasil cipta, karsa, dan karya manusia, termasuk di dalamnya bendabenda hasil kreativitas/ciptaan manusia. Namun dalam perspektif antropologi yang lebih kontemporer, kebudayaan didefinisikan sebagai suatu sistem simbol dan makna dalam sebuah masyarakat manusia yang di dalamnya terdapat norma- norma dan nilai-nilai tentang hubungan sosial dan perilaku yang menjadi identitas dari masyarakat bersangkutan. Dengan demikian, pariwisata budaya merupakan jenis pariwisata yang berdasarkan pada tempat, tradisi, kesenian, upacara-upacara, dan pengalaman yang memotret suatu bangsa/suku bangsa dengan masyarakatnya, yang merefleksikan keanekaragaman (diversity) dan identitas (character) dari masyarakat atau bangsa bersangkutan. (www.indonesiabeautiful.com diakses pada tanggal 13 Oktober 2017). Bali terkenal akan tradisi dan budayanya yang sudah menjadi pembicaraan di seluruh dunia. Kepariwisataan dipandang sebagai suatu industri jasa yang cukup memberikan harapan yang menjamin untuk kedepannya khususnya daerah Bali. Pariwisata Bali yang memperlihatkan corak wisata budaya, dalam perkembangannya melibatkan berbagai aspek kehidupan masyarakat Bali, seperti lingkungan alam, ekonomi, agama, kesenian dan kehidupan sosialnya. Dari perpaduan berbagai aspek kehidupan tersebut dalam masyarakat Bali telah menjadikan Bali menjadi daerah tujuan wisata yang begitu unik dan populer. Kabupaten Buleleng merupakan salah satu kabupaten yang terdapat di Provinsi Bali.

Kabupaten Buleleng merupakan kabupaten terluas di Provinsi Bali dengan luas wilayah lebih kurang $24,25 \%$ dari luas Provinsi Bali. Secara administrasi terdiri dari 9 kecamatan dengan 148 Desa/Kelurahan. Secara topografi Kabupaten Buleleng yang terletak di belahan utara Pulau Bali yang wilayahnya terdiri dari gunung, daratan dan laut utara Pulau Bali yang berbatasan dengan Laut Jawa/Bali, sehingga sebagian besar wilayah kabupaten merupakan kawasan pesisir dengan panjang pantai 157,05 Km dengan aneka ragam kekayaan laut. Dari penduduk yang berjumlah sebanyak 786.972 jiwa pada tahun 2009, sebayak 4.314 orang $(0.67 \%)$ bermata pencaharian sebagai nelayan. (www.bulelengkab.go.id diakses pada tanggal 23 Desember 2016).

Kabupaten Buleleng beberapa tahun terakhir ini mengoptimalkan pengembangan investasi pariwisata. Upaya ini ditempuh 
karena potensi pariwisata di daerah ini banyak yang belum dikelola optimal. Pengembangan ini tidak hanya dilakukan pemerintah, juga masyarakat lokal dan peran pihak ketiga (investor) semakin intens menggarap potensi pariwisata bahari, pemandangan alam, wisata agro, dan wisata budaya. Potensi wisata yang dimaksud dibagi menjadi tiga macam, yaitu:

1. Potensi Wisata Alam

Yang dimaksud dengan potensi wisata alam adalah keadaan, jenis flora dan fauna suatu daerah, bentang alam seperti pantai, hutan, pegunungan dan lain-lain (keadaan fisik suatu daerah). Kelebihan dan keunikan yang dimiliki oleh ala jika dikembangkan dengan memprhatikan keadaan lingkungan sekitarnya niscaya akan menarik wisatawan untuk berkunjung ke obyek tersebut.

2. Potensi Wisata Budaya

Yang dimaksud dengan potensi wisata kebudayaan adalah semua hasil cipta, rasa dan karsa manusia baik berupa adat istiadat, kerajinan tangan, kesenian, peninggalan sejarah berupa bangunan seperti monument dan candi.

3. Potensi Wisata Manusia

Potensi wisata manusia juga sebagai daya tarik wisata berupa, pementasan tarian, pementasan atau pertunjukan seni budaya suatu daerah.

Buleleng memiliki potensi wisata budaya yang belum banyak diketahui oleh wisatawan, khususnya di daerah kawasan wisata lovina. Selama ini kawasan wisata lovina hanya dikenal dengan wisata alamnya yakni pantai yang terkenal akan Dolphin Tournya dari Pantai Lovina sampai Pantai Hepi di Desa Pemaron. Sedangkan jika cermati terdapat banyak potensi wisata budaya seperti tradisi sampi gerumbungan, yang diselenggarakan satu tahun sekali dalam Event Lovina Festival, tradisi megebeg-gebegan yang ada di Desa Tukadmungga, adanya bangunan kuno seperti Candi Budha dan Pura Kawitan Majapahit di Desa Kalibukbuk dan peninggalan museum Anak Agung Panji Tisna di Desa Kalibukbuk. Dengan sudah adanya beberapa wisata budaya tersebut tidak menutup kemungkinan terdapat wisata budaya yang lainnya yang belum dikembangkan di Kawasan Wisata Lovina. Maka perlu halnya peneliti melakukan penelitian ini untuk mengkaji lebih banyak wisata budaya apa sajakah yang masih terdapat di Kawasan Wisata Lovina untuk dapat dikembangkan dan dikelola dengan baik. Menurut Pitana (2009:75), mengelompokkan terdapat 5 kelompok yang termasuk wisata budaya yaitu:

a) Bangunan bersejarah dan museum, b) Pusat seni dan Kerajinan Tangan, c) Peninggalan Keagamaan, d) Tradisi dan Adat Istiadat, e) Kuliner. Kawasan Wisata Lovina sendiri hanya dikenal sebagai wisata bahari yang populer akan ikan lumbalumbanya disepanjang Pantai Lovina hingga Pantai Hepi di Desa Pemaron. Tidak banyak yang tahu jika kawasan wisata lovina memiliki potensi objek wisata budaya yang dapat dikembangkan sehingga dapat menambah minat para wisatawan untuk berkunjung.

Berdasarkan latar belakang masalah tersebut di atas, maka dapat diambil perumusan masalah sebagai berikut:

1. Apa sajakah potensi objek wisata budaya di Kawasan Wisata Lovina?

Dengan tujuan untuk mengetahui apa saja potensi objek wisata budaya di Kawasan Wisata Lovina.

\section{METODE PENELITIAN}

Penelitian ini digolongkan ke dalam jenis penelitian deskriptif. Penelitian ini bertujuan untuk mendeskripsikan potensi wisata budaya yang ada di Kawasan Wisata Lovina. Lokasi penelitian ini adalah di Kawasan Wisata Lovina meliputi 7 desa yakni : Desa Pemaron, Desa Tukad Mungga, Desa Anturan, Desa Kalibukbuk, Desa Kaliasem, Desa Temukus, dan Desa Tigawasa. Dalam penelitian ini terdapat satu variabel yakni Potensi Objek Wisata Budaya di Kawasan Wisata Lovina dengan definisi operasional variabel yakni Potensi Objek Wisata Budaya adalah pengkajian seberapa banyak potensi objek wisata budaya yang terdapat di Kawasan Wisata Lovina. Objek wisata budaya dikelompokan menjadi 5 yaitu: (a) Bangunan Bersejarah 
dan Museum: seperti situs budaya kuno, monument dan atau museum (b) Pusat Seni dan Kerajinan Tangan: seperti barang atau produk yang memiliki nilai seni yang dibuat sendiri oleh masyarakat lokal di area objek wisata dan dapat dijadikan oleh-oleh atau cinderamata oleh wisatawan (c) Peninggalan Keagamaan, (d) Tradisi dan Adat Istiadat: seperti upacara keagamaan yang disakralkan, pakaian tradisional daerah tersebut serta kebiasaan-kebiasaan unik yang dilakukan di daerah tersebut (e) Kuliner: seperti masakan daerah setempat yang menjadi khasnya. Jenis data yang digunakan dalam penelitian ini, digolongkan menjadi dua jenis data yakni data primer yang diperoleh dari hasil wawancara yang peneliti lakukan dengan informan kunci yakni Kepala Dinas Pariwisata Kabupaten Buleleng yaitu Bapak Nyoman Sutrisna yang kemudian ditunjuklah masing-masing Kepala Desa di Kawasan Wisata Lovina yakni Kepala Desa Temukus, Kepala Desa Tigawasa, Kepala Desa Kalibukbuk, Kepala Desa Kaliasem, Kepala Desa Anturan, Kepala Desa Tukadmungga, Kepala Desa Pemaron untuk mendapatkan data mengenai potensi wisata budaya yang dapat dikembangkan di desanya yang dikelompokan menjadi 5 seperti adanya bangunan bersejarah dan museum, adanya pusat seni dan kerajinan tangan, adanya peninggalan keagamaan, adanya tradisi dan adat istiadat serta adanya kuliner khas di desa tersebut, dan data sekunder yang diperoleh dari telaah dokumen yang diberikan oleh Kepala Desa setempat mengenai peninggalan sejarah seperti penemuan prasasti, arca atau sarkopah yang merupakan suatu ciri kebudayaan pada zamannya. Adapun sumber data dari penelitian ini, ditentukan dengan menggunakan teknik snowball sampling. Snowball sampling adalah teknik penentuan sampel yang mula-mula jumlahnya kecil yang kemudian membesar seiring berlangsungnya penelitian. Dalam teknik snowball sampling, awalnya dipilih satu orang informan kunci, yang dalam penelitian ini yaitu Kepala Dinas Pariwisata Kabupaten Buleleng. Selanjutnya dari Kepala Dinas Pariwisata Kabupaten Buleleng mengarahkan peneliti kepada informan lain yang mengetahui tentang kebudayaan di desa setempat melalui Kepala Desa di masing-masing desa untuk didapatkan data yang tepat dan akurat. Kemudian kepala desa akan mengarahkan kepada unit-unit sosial yang mengetahui informasi dan data yang akurat mengenai sejarah desa dan pengelolaannya. Data yang terkumpul melalui wawancara dan telaah dokumen tersebut, kemudian dianalisis secara deskriptif dengan memilah data-data tersebut untuk menjawab rumusan masalah yang ada. Data yang terkumpul dianalisis agar menjadi informasi yang bermakna sesuai dengan permasalahan yang diteliti.

\section{HASIL DAN PEMBAHASAN}

Data hasil penelitian menyebutkan bahwa terdapat potensi objek wisata budaya di masing-masing desa yang merupakan bagian dari Kawasan Wisata Lovina yang meliputi 5 aspek, diantaranya (1) Bangunan bersejarah, (2) Pusat seni dan kerajinan tangan, (3) Peninggalan keagamaan, (4) Tradisi dan ada istiadat, serta (5) Kuliner. Adapun potensi wisata objek wisata budaya tersebut akan peneliti jabarkan per desa, sebagai berikut: 1. Desa Temukus memiliki potensi objek wisata budaya yang meliputi bangunan bersejarah yang terdiri dari Monumen Tugu Belanda dan Makam Keramat Karang Rupit, Pusat seni dan kerajinan tangan yang meliputi Krisna Wisata Oleh-oleh, memiliki tradisi dan adat istiadat yaitu menyajikan makanan dan minuman di pinggir jalan pada saat piodalan di Pura Labuan Aji, dan memiliki kuliner khas yaitu kecap meliwis dan ikan bakar yang sudah terkenal hampir di seluruh wilayah di Bali. 2. Desa Tigawasa memiliki potensi wisata budaya yang terdiri dari bangunan bersejarah yang meliputi sekaa roras atau rumah tua dengan 12 tiang penyangga, sarkopah yaitu batu untuk meletakkan mayat pada jaman dahulu, Gua Igemol, Gigin Kilap dan selonding yang merupakan alat musik sakral di Bali, memiliki pusat seni dan kerajinan tangan khas dari anyaman bambu yaitu sokasi yang sudah terkenal di Bali, memiliki peninggalan keagamaan yaitu hutan yang dipercaya sebagai tempat suci agama 
hindu atau pura namun tidak berwujud bangunan seperti pada umumnya, yang oleh masyarakat Desa Tigawasa disebut dengan mertiwi, memiliki tradisi dan adat istiadat yaitu Nyepi adat, upacara kematian yang khas, serta tradisi meboros kijang atau berburu rusa yang hanya dilakukan saat upacara Puja Wali di Desa Tigawasa, serta memiliki kuliner khas yaitu gula merah dan timbungan yang wajid ada pada saat upacara besar keagamaan di Desa Tigawasa. 3. Desa Kaliasem memiliki bangunan bersejarah yaitu The Little Museum Anak Agung Pandji Tisna sebagai bentuk penghormatan dan penghargaan kepada pencipta Lovina yang terkenal ini, serta memiliki tradisi sapi gerumbungan yaitu lomba karapan sapi yang saat ini selalu diadakan pada saat Lovina festival. 4. Desa Kalibukbuk sebagai pusat dari Kawasan Wisata Lovina memiliki bangunan bersejarah yang meliputi Puri Ayodya, memiliki pusat seni dan kerajinan tangan yaitu Art Shop Pantai Binaria sebagai pusat penjual oleh-oleh dan cinderamata khas Lovina, serta memiliki kesenian tari cetik geringsing yang menceritakan asal terbentuknya Banyualit sebagai salah satu bagian dari Desa Kalibukbuk, memiliki peninggalan keagamaan yang berupa Candi Budha Kalibukbuk sebagai candi terbesar di Kabupaten Buleleng, serta Pura Kawitan Majapahit. 5. Desa Anturan memiliki bangunan bersejarah yaitu Pemandian Tirta Mumbul sebagai pemandian untuk menyucikan diri atau melukat bagi umat hindu, memiliki pusat seni dan kerajinan tangan yaitu tari gambuh, rindik yang merupakan alat musik tradisional dari bahan bambu, serta ingka

Berdasarkan paparan tersebut, maka dapat dijelaskan bahwa Kawasan Wisata Lovina memiliki berpotensi sebagai kawasan objek wisata budaya di Kabupaten Buleleng.

\section{PEMBAHASAN}

Dalam buku Pengantar Pariwisata
yang ditulis oleh Pitana (2009:75)
menyebutkan bahwa objek wisata budaya
dikelompokkan menjadi 5 yaitu:

atau kerajinan tangan dari lidi yang digunakan umat hindu sebagai alat persembahyangan. 6. Desa Tukadmungga memiliki bangunan bersejarah yaitu pemandian dengan 12 sumber mata air, memiliki pusat seni dan kerajinan tangan diantaranya penghasil kerajinan batu bata merah di Kabupaten Buleleng, kerajinan batu pahat Dusun Sabak, serta kesenian tari sanghyang dedari dan sanghyang memedi yang merupakan tarian suci dan sakral yang hanya boleh dipentaskan pada hari-hari tertentu saja. Desa Tukadmungga juga memiliki peninggalan keagamaan yaitu Pura Jro Alus yang memiliki keunikan dimana umat hindu yang sembahyang ke pura tersebut tidak boleh menghidukan api yang mana api dalam agama hindu merupakan salah satu sarana upacara agama, dan memiliki Pura Taman yang memiliki 12 sumber mata air, juga memiliki tradisi dan adat istiadat yaitu megebeggebegan yang merupakan salah satu tradisi yang sangat terkenal di Bali, dimana dalam tradisi tersebut dua kelompok pemuda akan memperebutkan kepala sapi sebagai persembahan pada saat hari pengerupukan (sehari menjelang hari raya nyepi). Selain itu Desa Tukadmungga juga memiliki tradisi ngelawang barong yang diadakan pada saat upacara keagamaan di desa tersebut. 7. Desa Pemaron memiliki pusat seni dan kerajinan tangan yaitu wayang kulit dan peninggalan keagamaan yaitu Pura Siwa Manik Dalang sebagai pusat penyucian bagi dalang dan wayang yang ada di seluruh wilayah di Kabupaten Buleleng. Untuk lebih jelas, potensi wisata budaya di masing-masing desa di Kawasan Wisata Lovina.

1. Bangunan bersejarah dan museum yang terdiri dari bangunan rumah tua, museum peninggalan sejarah, gedung tua, makam bersejarah, perpustakaan, pameran, festival, situs budaya kuno, dan prasasti.

2. Pusat seni dan kerajinan tangan yang terdiri dari pasar seni, anyaman lidi, kerajinan bambu, lukisan, kerajinan logam, kerajinan kayu, kain tenun, wayang kulit, kerajinan 
keramik/tembikar, lagu daerah, dan seni pertunjukan.

3. Peninggalan keagamaan yang terdiri dari pura, candi, masjid, wihara, gereja, dan kuil.

4. Tradisi dan adat istiadat yang terdiri dari pakaian tradisional, upacara adat, teknologi tradisional, system kehidupan daerah setempat, sanggar, dan tradisi.

5. Wisata kuliner yang termasuk di dalamnya makanan dan minuman khas daerah setempat.

Berpijak dari teori tersebut, potensi wisata budaya yang terdapat di Kawasan Wisata Lovina memenuhi kelima potensi tersebut yang sesuai dengan yang diungkapkan oleh Pitana (2009:75) yang meliputi bangunan bersejarah dan museum, pusat seni dan kerajinan tangan, peninggalan keagamaan, tradisi dan adat istiadat, serta wisata kuliner. Hanya saja tidak setiap desa memiliki kelima potensi wisata budaya tersebut. Namun hal ini dapat dijadikan sebagai upaya untuk meratakan sebaran wisatawan sehingga tidak terpusat pada pusat kawasan wisata lovina yaitu Desa Kalibukbuk dan Kaliasem.

\section{Bangunan Bersejarah dan Museum di Kawasan Wisata Lovina}

Bangunan bersejarah dan museum merupakan bangunan yang ditinggalkan oleh leluhur atau pejuang di masa dulu dan sampai saat ini masih terdapat bekas peninggalan tersebut. Adapun bangunan bersejarah dan museum yang ada di Kawasan Wisata Lovina yaitu (1) Tugu Belanda yang merupakan peninggalan dari zaman penjajahan Belanda di Buleleng dan Makam Keramat Karang Rupit yang merupakan makam peninggalan muslim cina yang peziarahnya tidak hanya muslim saja, melainkan semua umat yang ingin melakukan ziarah ke makam tersebut yang masing-masing berada di Desa Temukus, (2) Sekaa Roras atau rumah tua dengan 12 tiang penyangga yang biasa digunakan untuk tempat banten atau sesembahan sebelum upacara, Sarkopah, Gua I Gemol, Gigin Kilap atau kapak batu halus yang disucika, serta selonding atau alat musik khas yang berasal dari Desa Tigawasa, (3) Little Museum Anak Agung Panji Tisna yang terdapat di Desa Kaliasem yang dibangun untuk memperkenalkan pendiri Lovina, (4) Puri Ayodya yang dibangun sejak tahun 1903 yang merupakan tempat untuk menyimpan benda-benda bersejarah peninggalan kerajaan Buleleng yang terdapat di Desa Kalibukbuk, (5) Pemandian Tirta Mumbul yang terdapat di Desa Anturan, serta (6) Pemandian dengan 12 sumber mata air yang terdapat di Desa Tukad Mungga. Peninggalan bersejarah tersebut hendaknya lebih dipromosikan sehingga tujuan wisatawan ke Kawasan Wisata Lovina tidak hanya pada wisata lumba-lumba saja, namun pada peninggalan sejarah pula.

\section{Pusat Seni dan Kerajinan Tangan di Kawasan Wisata Lovina}

Pusat seni dan kerajinan tangan merupakan hasil seni yang diciptakan oleh masyarakat suatu daerah sehingga menjadi ciri khas dari daerah tersebut. Adapun pusat seni dan kerajinan tangan yang terdapat di Kawasan Wisata Lovina yaitu (1) Krisna wisata oleh-oleh yang menjual segala oleh-oleh khas Bali termasuk oleholeh khas Buleleng yang dibangun sejak tahun 2017 di Desa Temukus, (2) Anyaman Bambu (sokasi) yang merupakan anyaman khas dari Desa Tigawasa yang sudah terkenal hampir di seluruh wilayah di Bali. Desa Tigawasa sendiri merupakan penghasil bambu terbesar di Buleleng, sehingga kualitas dari anyaman yang dihasilkan tergolong sangat baik, (3) Art Shop Pantai Binaria yang berada di pusat Kawasan Wisata Lovina yaitu di Desa Kalibukbuk yang menyediakan oleh-oleh khas dari Lovina yang berupa patung lumba-lumba sebagai ikon wisata Lovina, dan tari cetik gringsing yang merupakan tari yang menceritakan tentang awal berdirinya Desa Pakraman Banyualit yang merupakan bagian dari Desa Kalibukbuk, (4) Tari Gambuh yang merupakan tarian khas dari Desa Anturan, Rindik yang merupakan alat musik berbahan bambu yang biasa digunakan untuk mengiringi tarian joged di Desa Anturan, serta Ingka atau anyaman lidi yang dihasilkan oleh sebagian besar ibu-ibu di Desa Anturan, (5) Batu bata merah merupakan kerajinan khas dari Desa 
Tukad Mungga yang juga merupakan salah satu pusatnya pengrajin batu bata merah di Buleleng, Kerajinan Pahat Batu Subak yang sudah terkenal sampai keluar negeri, serta Tari Sang Hyang Dedari dan Sang Hyang Memedi yang sampai saat ini mulai jarang ditarikan sehingga untuk melestarikan warisan tersebut,Pemerintah mementaskan kedua tari itu di acara Buleleng Festival dan Lovina Festival setiap tahunnya di Buleleng, (6) Wayang kulit yang merupakan kerajinan khas Desa Pemaron. Wayang kulit memang banyak ditemukan di daerah lain, namun sebagai pusat penyucian wayang tersebut, maka wayang kulit Desa Pemaron yang paling terlihat keberadaannya.

\section{Peninggalan Keagamaan di Kawasan Wisata Lovina}

Peninggalan

keagamaan

merupakan peninggalan yang berupa tempat suci seperti pura, masjid, gereja, wihara, atau kuil dari zaman kerajaan atau zaman penyebaran agama oleh orang suci. Di Kawasan Wisata Lovina terdapat beberapa peninggalan keagamaan sejak zaman kerajaan terdahulu yang sampai saat ini masih bertahan, diantaranya (1) Mertivi atau hutan yang dijadikan sebagai tempat suci atau pura namun tidak dalam wujud bangunan yang terdapat di Desa Tigawasa. Sebagian besar areal hutan di Desa Tigawasa dianggap sakral oleh penduduk desa, sehingga tidak sembarang orang bisa memasukinya. Areal hutan hanya boleh dimasuki pada saat diselenggarakannya piodalan di hutan tersebut, (2) Candi Budha Kalibukbuk yang merupakan situs budaya kuno yang berhasil ditemukan sejak tahun 2009 oleh masyarakat Desa Kalibukbuk. Candi Budha Kalibukbuk sampai saat ini dijadikan sebagai salah satu objek wisata budaya yang dapat dikunjungi oleh wisatawan yang ingin tahu dan belajar mengenai warisan budaya di Lovina, dan Pura Kawitan Majapahit yang memiliki keterkaitan dengan keberadaan Candi Budha Kalibukbuk tersebut, (3) Pura Taman dengan 12 sumber mata air dan Pura Jro Alus yang memiliki ciri khas yaitu bagi umat hindu yang ingin melakukan persembahyangan ke pura tersebut, tidak diperkenankan untuk menyalakan api atau dupa seperti persembahyangan pada umumnya di Desa Tukad Mungga, dan (4) Pura Siwa Manik Dalang yang merupakan pura yang dijadikan sebagai pusat penyucian dalang dan wayang di seluruh wilayah di Kabupaten Buleleng. Pura ini berada di Desa Pemaron.

\section{Tradisi dan Adat Istiadat di Kawasan Wisata Lovina}

Tradisi dan adat istiadat merupakan ciri khas dan aturan tersendiri bagi setiap desa dalam menyelenggarakan sistem desanya. Tradisi dan adat istiadat ini dapat menjadi atraksi wisata budaya yang dapat disaksikan oleh wisatawan yang berkunjung ke desa tersebut, sehingga akan dapat menguntungkan bagi desa itu sendiri. Tradisi dan adat istiadat di Kawasan Wisata Lovina yang sampai saat ini dilestarikan di masing-masing desa yang menjadi bagian dari kawasan tersebut, diantaranya (1) Upacara Madyaning Karya Pamulungan Agung di Pura Labuan Aji yakni menyajikan makanan di pinggir jalan saat piodalan di Pura Labuan Aji, Desa Temukus. Masyarakat Desa Temukus akan menyediakan makanan dan minuman bagi orang-orang yang mengiringi adegan atau simbol Dewa (Tuhan) dalam Agama Hindu saat dilaksanakannya upacara suci di Pura Labuan Aji sebagai bentuk ucapan terima kasih karena telah membantu upacara tersebut sehingga berjalan lancar, (2) Nyepi adat di Desa Bali Aga setelah upacara pujawali, Upacara kematian yang tidak menggunakan dewasa ayu dan harus dikubur segera setelah kematian atau didiamkan selama tiga hari jika akan dilanjutkan dengan upacara pengabenan, dan acara Meboros atau berburu rusa sebelum upacara pujawali sebagai salah satu persembahan dalam acara pujawali di Desa Tigawasa tersebut, (3) Sampi Gerumbungan di Desa Kaliasem yang merupakan tradisi khas sejak dahulu yang memiliki makna sebagai ucapan syukur dan terima kasih setelah panen padi berakhir. Tradisi ini sering ditampilkan setiap tahunnya pada saat Lovina Festival dan merupakan ikon bagi penyelenggaraan Lovina Festival di Lovina, (4) Megebeg- 
gebegan yang merupakan tradisi khas Desa Tukad Mungga yang dilaksanakan pada saat pengerupukan atau sehari sebelum hari raya Nyepi. Tradisi ini sangat unik, dimana dua kelompok pemuda akan memperebutkan kepala godel (anak sapi) yang merupakan salah satu persembahan pecaruan. Bagi kelompok pemuda yang menang, akan membawa kepala godel tersebut pulang untuk dinikmati bersama keluarganya dan kelompoknya dan tradisi Ngelawang Barong Bangkal yang merupakan tradisi yang masih disakralkan sampai saat ini. Namun, untuk upaya promosi maka pemerintah menampilkan ngelawang barong bangkal pada saat Buleleng festival setiap tahunnya.

\section{Wisata Kuliner di Kawasan Wisata Lovina}

Wisata kuliner merupakan makanan dan minuman yang menjadi ciri khas dari suatu daerah. Kawasan Wisata Lovina yang terdiri dari tujuh desa, juga memiliki makanan dan minuman yang menjadi ciri khas yang berpotensi untuk dijadikan objek wisata diantaranya (1) Ikan Bakar dan Kecap Meliwis yang merupakan kuliner khas Desa Temukus. Ikan merupakan salah satu hasil laut di Desa Temukus, sehingga di daerah ini dapat ditemukan banyak warung makan ikan bakar dengan bumbu khas nya. Selain ikan bakar, Desa Temukus juga merupakan penghasil kecap yaitu kecap meliwis yang sudah terkenal sampai ke seluruh wilayah di Bali, (2) Gula Merah Desa Tigawasa merupakan gula dengan kualitas terbaik di Kawasan Wisata Lovina. Gula ini juga sudah dipasarkan keluar daerah desa atau bahkan di beberapa daerah di Buleleng. Selain gula merah, Desa Tigawasa juga memiliki makanan khas yaitu timbungan yang merupakan proses pengolahan makanan yang dimasukkan ke dalam bambu kemudian dibakar. Makanan yang biasa dimasak dengan pengolahan ini yaitu lawar. Di Desa Tigawasa, timbungan ini wajib ada pada saat diadakannya upacara keagamaan.

\section{SIMPULAN DAN SARAN}

Berdasarkan hasil analisis data dan pembahasan yang sudah dipaparkan, maka simpulan penelitian ini sebagai berikut :

1. Kawasan Wisata Lovina memiliki potensi yang besar untuk dijadikan sebagai salah satu kawasan wisata budaya di Kabupaten Buleleng yang dapat dilihat dari adanya 5 aspek atau syarat wisata budaya, diantaranya (1) Bangunan bersejarah dan museum yang berupa Tugu Belanda dan Makam Keramat Karang Rupit dari Desa Temukus, Seka Roras, Sarkopah, Gua I Gemol, Gigin Kilap, dan Selonding dari Desa Tigawasa, Little Museum Anak Agung Panji Tisna dari Desa Kaliasem, Puri Ayodya di Desa Kalibukbuk, Pemandian Tirta Mumbul di Desa Anturan, dan Pemandian dengan 12 sumber mata air di Desa Tukad Mungga, (2) Pusat seni dan kerajinan tangan yang berupa Krisna wisata oleh - oleh di Desa Temukus, Anyaman bambu (sokasi) di Desa Tigawasa, Art Shop Pantai Binaria dan kesenian Tari Cetik Gringsing di Desa Kalibukbuk, Tari Gambuh, Rindik dan Ingka (anyaman lidi) di Desa Anturan, Batu Bata Merah, Kerajinan Pahat Bau Dusun Subak, dan Tari Sanghyang Memedi dan Sanghyang Dedari di Desa Tukad Mungga, serta Wayang Kulit di Desa Pemaron, (3) Peninggalan keagamaan yang berupa Mertiwi di Desa Tigawasa, Candi Budha Kalibukbuk dan Pura Kawitan Majapahit di Desa Kalibukbuk, Pura Taman dan Pura Jro Alus di Desa Tukad Mungga dan Pura Siwa Manik Dalang di Desa Pemaron, (4) Tradisi dan adat istiadat yang berupa menyajikan makanan di pinggir jalan saat piodalan di Pura Labuan Aji, Desa Temukus, Nyepi adat, Upacara kematian, dan Meboros Kijang (rusa) di Desa Tigawasa, Sampi Gerumbungan di Desa Kaliasem, Megebeggebegan dan Ngelawang Barong Bangkal di Desa Tukad Mungga, (5) Wisata Kuliner yang berupa Ikan bakar dan Kecap Meliwis Desa Temukus, Gula Merah dan Timbungan di Desa Tigawasa.

Berdasarkan simpulan di atas, dapat dikemukakan saran-saran sebagai berikut.

1. Untuk masyarakat di masing-masing yang menjadi bagian Kawasan Wisata 
Lovina agar lebih memperhatikan dan menjaga peninggalan bersejarah yang dapat dijadikan sebagai objek wisata budaya di daerah tersebut sehingga wisatawan semakin banyak yang datang berkunjung.

2. Bagi Pemerintah Desa agar mampu untuk mengawasi warisan budaya yang ada sehingga tidak hilang atau punah.

3. Bagi Pemerintah Kabupaten Buleleng agar lebih menggali lagi informasi mengenai warisan budaya yang ada di masing-masing desa sehingga upaya untuk menjadikan Kawasan Wisata Lovina sebagai kawasan wisata budaya dapat segera diwujudkan sehingga hal ini akan bedampak pada peningkatan jumlah kunjungan wisatawan yang datang ke Lovina.

4. Untuk peneliti lain yang tertarik dengan penelitian mengenai potensi wisata budaya di Kawasan Wisata Lovina dapat melanjutkan penelitian ini dengan mengkaji aspek aspek lain yang berhubungan dengan Kawasan Wisata Lovina.

\section{DAFTAR PUSTAKA}

Ardharianti, Titin. 2009. Kajian potensi sumber daya pantai nirwana untuk kegiatan wisata pantai di kota baubau, Provinsi sulawesi tenggara. Jurnal pariwisata Volume 6. Nomor 3, April 2011, tersedia dalam http://eprints. Unes.ac.id//titin ardharianti.pdf. (diakses pada tanggal 15 Desember 2016).

Artikel Bali Travel INews Tersedia pada http://bali-

travelnews.com/2017/05/09/bulelenggenjot-sektor-pariwisata/ (di akses pada tanggal 19 Oktober 2017)

Artikel Pariwisata Indonesia Tersedia pada http://pariwisatacu.blogspot.co.id/201 1/07/upaya-meningkatkanpariwisata.html (diakses pada tanggal 13 Oktober 2017)
Erawan, Nyoman. 1994. Pariwisata dan Pengembangan Ekonomi (Bali sebagai kasus). Denpasar : Upadasas.

Febriani, S Ni Nyoman. 2013. Kajian Potensi Pasar Seni Sukawati sebagai Objek Wisata Budaya DI Desa Sukawati Kecamatan Sukawati Kabupaten Gianyar (Tinjauan Geografi). Skripsi. Singaraja : Universitas Pendidikan Ganesha.

Marpaung, Happy. 2002. Pengetahuan Kepariwisataan. Bandung : Alfabet.

Pendit, S Nyoman. 2002. Ilmu Pariwisata sebuah pengantar perdana. Jakarta : Pradnya Paramitha.

Sujarweni, V. Wiratna. 2014. Metodologi Penelitian. Yogyakarta:Pustaka Baru

Suwena, I Ketut. 2010. Pengetahuan Dasar IImu Pariwisata.Denpasar:Udayana University Press

Suwantoro, Gamal. 2004. Dasar-dasar Pariwisata. Yogyakarta: Andi

Undang-undang Nomor 9 Tahun 1990 tentang Pariwisata

Yoeti, H. Oka. A. 1999. Industri Pariwisata dan Peluang Kesempatan Kerja. Jakarta: Pertja

Yoeti, A. Oka, dkk. 2004. Pariwisata Budaya Masalah dan Solusinya. Jakarta: Pradnya Paramita 
Jurnal Bosaparis: Pendidikan Kesejahteraan Keluarga

Volume 9, Nomor 1, Maret 2018 
Jurnal Bosaparis: Pendidikan Kesejahteraan Keluarga

Volume 9, Nomor 1, Maret 2018 